University of Wollongong

Research Online

Faculty of Law, Humanities and the Arts Papers (Archive)

$1-1-2014$

Dispute settlement in the Law of the Sea Convention and territorial and maritime disputes in Southeast Asia: issues, opportunities, and challenges

Lowell Bautista

University of Wollongong, lowell@uow.edu.au

Follow this and additional works at: https://ro.uow.edu.au/lhapapers

Part of the Arts and Humanities Commons, and the Law Commons

Research Online is the open access institutional repository for the University of Wollongong. For further information contact the UOW Library: research-pubs@uow.edu.au 


\title{
Dispute settlement in the Law of the Sea Convention and territorial and maritime disputes in Southeast Asia: issues, opportunities, and challenges
}

\begin{abstract}
The 1982 United Nations Convention on the Law of the Sea (LOSC) provides for a dispute settlement regime that establishes a compulsory and binding framework for the peaceful settlement of all oceanrelated disputes. In Southeast Asia, despite the long-standing myriad of territorial and maritime disputes, there appears to be a general reluctance to utilize the dispute settlement provisions of LOSC. The region has very little experience in international litigation involving territorial and maritime disputes, and a reluctance to utilize the dispute settlement provisions of LOSC. While the LOSC legal framework offers some options, the highly complicated nature of the disputes in the region, especially those pertaining to the overlapping and conflicting claims over the South China Sea, cultural factors, and other pragmatic considerations, test the limits of international lawand obscure the possibility of a legal solution.
\end{abstract}

\section{Keywords}

law, sea, convention, territorial, dispute, maritime, settlement, disputes, southeast, asia, issues, opportunities, challenges

\section{Disciplines}

Arts and Humanities | Law

\section{Publication Details}

Bautista, L. (2014). Dispute settlement in the Law of the Sea Convention and territorial and maritime disputes in Southeast Asia: issues, opportunities, and challenges. Asian Politics and Policy, 6 (3), 375-396. 


\title{
Dispute Settlement in the Law of the Sea Convention and Territorial and Maritime \\ Disputes in Southeast Asia: Issues, Opportunities and Challenges \\ Lowell Bautista*
}

\begin{abstract}
The 1982 United Nations Convention on the Law of the Sea (LOSC) provides for a dispute settlement regime that establishes a compulsory and binding framework for the peaceful settlement of all ocean-related disputes. In Southeast Asia, despite the longstanding myriad of territorial and maritime disputes, there appears to be a general reluctance to utilize the dispute settlement provisions of LOSC. The region has very little experience in international litigation involving territorial and maritime disputes and a reluctance to utilize the dispute settlement provisions of LOSC. Whilst the LOSC legal framework offers some options, the highly complicated nature of the disputes in the region especially those pertaining to the overlapping and conflicting claims over the South China Sea, cultural factors and other pragmatic considerations, test the limits of international law and obscure the possibility of a legal solution.
\end{abstract}

\section{Keywords}

Dispute Settlement, Law of the Sea Convention, Territorial and Maritime Disputes, Southeast Asia

\footnotetext{
* Lowell Bautista, PhD, is a Lecturer at the School of Law and a Staff Member at the Australian National Centre for Ocean Resources and Security (ANCORS), Faculty of Law, Humanities and the Arts, University of Wollongong. He is also an Associate Fellow at the Higher Institution Centre of Excellence (HICoE) Programme, Institute of Oceanography and Environment (INOS), University Malaysia Terrenganu, Malaysia. This is a revised and updated version of a paper of the same title presented by the author at "UNCLOS at 30", International Conference for the Anniversary of Signature of the United Nations Convention on the Law of the Sea, Qingdao, China, 22-24 November 2012.
} 


\section{Introduction}

The peaceful settlement of disputes over territory and over unresolved maritime boundaries is fundamental for the prevention of inter-State conflict and often a necessary pre-condition for the exploration and exploitation of resources and the preservation and protection of the marine environment. (Blake, 1998, pp. 3-27; Kwiatkowska, 1993, pp. 77-78) Disputed territorial sovereignty and contested maritime boundaries impair maritime security, hamper effective inter-State cooperation, compromise sustainable use of scarce natural resources, and hinder the flow of goods and resources. (Buszynski and Sazlan, 2007, p. 143; Prabhakar, 2007, pp. 34-48) However, despite the unarguable imperative for clearly delineated State boundaries, many of the world's territorial and maritime boundaries have yet to be resolved and delimited. (Smith, 1982, p. 3; Prescott and Schofield, 2005, p. 245; Antunes, 2003, pp. 45). In the resolution of these disputes, States submit their competing claims before an international court or tribunal for adjudication, effected through an agreement on the basis of international law. Consequently, there have been more judgments and awards concerning maritime boundary disputes than any other aspect of international law, an apparently continuing trend. (Kaikobad, 2002, pp. 1-86; Charney, 1994, p. 227)

The 1982 United Nations Convention on the Law of the Sea (LOSC) provides for a dispute settlement mechanism that establishes a compulsory and binding framework for the peaceful settlement of all ocean-related disputes. However, it must be emphasized that the rules laid down in the LOSC proceeds from the premise of existing and uncontested land features and could not be invoked as a source of title to territory. International law provides for five traditional modes of acquiring sovereignty: occupation, prescription, accretion, cession and conquest. (Jennings, 1963; Sharma, 1997, p. 5). The LOSC does not directly address disputes over sovereignty. The LOSC contains provisions, rather, for the delimitation of the territorial sea, the exclusive economic zone (EEZ) and the continental shelf, Articles 15, 74 and 83 of the LOSC, respectively.

It is clear that the LOSC does not address issues of competing claims to sovereignty over maritime features. The answer to the question of ownership over disputed insular features is not in the LOSC. This is addressed in public international law, of which the Law of the Sea, is a part. The rules governing the acquisition of territory are well established in customary 
international law and in international jurisprudence. It is not a shortcoming of the Convention that it does not address this issue. However, whilst the LOSC does not contain substantive provisions regarding solutions to address competing issues of ownership, it does provide for a dispute settlement mechanism which allows States parties to submit disputes (concerning the interpretation or application of the Convention) to a binding procedure as specified in Part XV, including sovereignty disputes with their consent, and in the forum of their choice, if they so please.

In the case of Southeast Asia, despite the longstanding myriad of territorial and maritime disputes, there appears to be a general reluctance to utilize the dispute settlement provisions of LOSC. Generally, the states in Southeast Asia have very little experience in litigation at the international level with regard to the settlement of territorial and maritime disputes, with only three disputes referred to the International Court of Justice (ICJ) and two cases submitted to the International Tribunal on the Law of the Sea (ITLOS) to date. The first territorial dispute case referred to the ICJ was in 1959 concerning the Temple of Preah Vihear between Cambodia and Thailand; the second was in 1998 when Indonesia and Malaysia went to the ICJ to resolve their sovereignty dispute over Pulau Ligitan and Pulau Sipadan (at which the Philippines filed an unsuccessful intervention in 2001); and the last was in 2003 when Malaysia and Singapore jointly submitted a request to resolve their territorial disputes regarding Pedra Branca (known as Pulau Batu Puteh in Malaysia), Middle Rocks and South Ledge (Malaysia/Singapore). The two ITLOS cases were: Case No. 12, concerning land reclamation by Singapore in and around the Straits of Johor between Malaysia and Singapore and Case No. 16, concerning delimitation of the maritime boundary between Bangladesh and Myanmar in the Bay of Bengal.

Since the LOSC came into force in 1994, there have been nine (9) Annex VII arbitrations. The Permanent Court of Arbitration (PCA), is acting, or has acted, as registry in eight of those cases. The PCA, it must be noted, is not a court in the conventional sense but an administrative organization providing registry services to resolve disputes arising out of treaties and agreements with the provision for arbitration (Brownlie, 2008, 703; Starke, 1984,466 , who notes of its "peculiar" nature as it neither "permanent" nor is it a "court.") 
There have been three (3) LOSC Annex VII arbitrations filed by states in the region where the PCA has acted as registry. The first one is the arbitration between Bangladesh and India concerning the delimitation of the maritime boundary in the Bay of Bengal instituted in October 2009 and is still pending. The second one is the arbitration between Malaysia and Singapore, instituted in July 2003 and terminated by an award on agreed terms rendered in 2005. Finally, the third case is the arbitration filed by the Philippines against China principally challenging, inter alia, China's claim in the South China Sea. (Bautista, 2013, pp. 520-524)

This paper will explore why the majority of territorial disputes in Southeast Asia have very little likelihood of being resolved through international adjudication especially through the dispute settlement regime under the LOSC. It will investigate the reasons behind the general reluctance among Southeast Asian countries to submit their disputes to a third-party dispute settlement procedure and also look at other methods of dispute resolution available at the international level.

This paper will be of three parts. The first part will describe the general principles of international law on the settlement of disputes and the system of dispute settlement in Part XV of the LOSC. The second part will look at the maritime region of Southeast Asia with an overview of territorial and maritime disputes in the region. The last part will discuss opportunities, challenges and recommendations.

\section{International law on the settlement of disputes}

\subsection{General principles}

International law once allowed the use of armed force as a means for States to resolve their disputes. Brownlie opines that State practice of 19th century Europe permitted the resort to war as a form of dispute settlement being an attribute of Statehood. (2008, p. 730) The illegality of the use of force by States is now considered a customary rule of international law, permissible only in the exercise of individual or collective self-defence or in certain exceptional instances allowed in customary law. (Brownlie, 2002, p. 130) The Charter of the United Nations (UN Charter, 1945) in Article 2(3) provides that "All Members shall settle their international disputes by peaceful means in such a manner that international peace 
and security, and justice, are not endangered." At present, the prohibition on the threat or use of force is not only a treaty obligation but has attained the status of a customary principle of international law binding upon all States. (Shaw, 2008, p. 1123; Gray, 2008, p. 30)

The UN Charter in Article 33 further provides that the parties to any dispute likely to endanger international peace and security are obliged to seek a solution by negotiation, enquiry, mediation, conciliation, arbitration, judicial settlement, resort to regional agencies or arrangements, or other peaceful means of their own choice. The LOSC in Article 279 explicitly refers to both Articles 2(3) and 33 of the UN Charter thereby reiterating the obligation of states parties to the convention to settle disputes by peaceful means.

The UN Charter clearly states that the International Court of Justice (ICJ) is the principal judicial organ of the United Nations. (Article 92, UN Charter) The ICJ exercises jurisdiction over legal disputes between States on issues of international law referred to it by the parties on the basis of the consent of the parties. (Article 36(1), ICJ Statute, 1945; Shaw, 2008, p. 1075) The ICJ will not take cognizance of a case involving a State unless both parties to the dispute have given their consent.

The ICJ has had a long history in resolving law of the sea disputes. It is widely recognised that the Court has particular expertise in territorial and maritime boundary cases. (Kwiatkowska, 2002) The pre-eminence of the ICJ in this area of international law has been firmly established from the earliest case filed with the court in 1947, the Corfu Channel to the latest one, which was promulgated in 2012, the Territorial and Maritime Dispute between Nicaragua and Colombia.

In 2013, out of eleven pending cases before the ICJ, three involve territorial and maritime boundary issues, the Frontier Dispute (Burkina Faso/Niger) filed in 2010, Maritime Dispute (Peru v. Chile) filed in 2008, the Request for interpretation of the Judgment of 15 June 1962 in the case concerning the Temple of Preah Vihear (Cambodia v. Thailand) filed in 2011. There is also another law of the sea-related case currently pending with the ICJ concerning Whaling in the Antarctic (Australia v. Japan, New Zealand intervening) filed in 2010. There have been more judgments and awards concerning maritime boundary disputes than any other aspect of international law, a trend which is apparently continuing. 


\subsection{Dispute Settlement within the framework of the LOSC}

The dispute resolution mechanism integrated into the LOSC is both complex and innovative. The compulsory adjudicative procedures in the LOSC are a sharp departure from traditional international dispute settlement where consent of the parties is normally required before the submission of a dispute to arbitration or adjudication. (Klein, 2009, 2) It is considered a central pillar of the convention and part of the delicate compromises included in the "package deal" of negotiations that led to the adoption of the LOSC in 1982. (Adede, 1987, p. 241). In order to preserve this delicate balance, the LOSC clearly prohibits States from making any reservations or exceptions. (Article 309, LOSC) According to Klein, "No additional form of consent is required once a State is party to the Convention - consent to be bound by UNCLOS includes consent to compulsory procedures entailing binding decisions (subject to Sections 1 and 3 of Part XV). Under Section 2, the States in dispute do not need (both or all) to consent to the referral of the dispute to court or tribunal, but the dispute can be submitted at the behest of just one of the disputant States." $(2009$, p. 53).

The dispute settlement system under the LOSC is contained in Part XV of the Convention. The provisions of Part XV are only applicable when there is a 'dispute' and it relates to either the 'interpretation' or 'application' of the Convention. (Article 286, LOSC) In addition to the requirement that there is a dispute, the dispute must be 'legal' or 'justiciable' in that it must be capable of being settled by the application of principles and rules of international law. (Lauterpacht, 2011, p. 64) Furthermore, Article 293 of the LOSC states that the court or tribunal having jurisdiction shall apply the Convention and "other rules of international law not incompatible with this Convention." The dispute settlement regime in Part XV of the LOSC is comprised of 3 sections. Section 1 contains the general provisions concerning dispute settlement; Section 2 outlines the compulsory procedures entailing binding decisions, and Section 3 provides for the limitations and exceptions to the applicability of Section 2.

The question of what constitutes a legal dispute is an old and enduring question but not exactly a perplexing question in international law. (Amerasinghe, 2009, pp. 46-47) There have been several international cases in the Permanent Court of International Justice (PCIJ) and the International Court of Justice (ICJ) which squarely addressed this issue such as the 
1924 PCIJ case of Mavrommatis Palestine Concessions between Greece and Great Britain and the ICJ decisions in the Case Concerning Military and Paramilitary Activities in and against Nicaragua between Nicaragua and the United States of America and the 2004 ICJ Advisory Opinion in the Legal Consequences of the Construction of a Wall in the Occupied Palestinian Territory, and indeed by a number of scholars. The PCIJ definition enunciated in the Mavrommatis Palestine Concessions case, that a 'dispute is a disagreement on a point of law or fact, a conflict of legal views or of interests between two persons (1924 PCIJ (Ser. A) No. 2, p. 11) and the ICJ's ruling in the Interpretation of the Peace Treaties with Bulgaria, Hungary and Romania, Advisory Opinion of 30 March 1950, as 'a situation in which the two sides held clearly opposite views concerning the question of the performance or nonperformance of certain treaty obligations,' (1950 ICJ Rep. 65, p. 74) have been widely adopted by other international tribunals. (Schreuer, 2008, p. 960)

The issue of whether a dispute exists is in fact a crucial one and of particular relevance to the discourse of disputes in Southeast Asia, especially in the context of the strong nationalist rhetoric utilized in the disputes over the South China Sea. China, for instance, has repeatedly claimed that it exercises "indisputable sovereignty" over the South China Sea. (Dillon, 2011, p. 54; To, 1999, p. 166) In principle, a dispute which is purely political without any legal connotations is not justiciable and cannot be taken cognizance of by any international court or tribunal. In fact, in actual practice, parties to a dispute refute the existence of a dispute for the purpose of contesting the jurisdiction of an international court or tribunal. (Schreuer, 2008, p. 959) In the case of the LOSC, if a dispute arises whether a court or tribunal has jurisdiction, that court or tribunal is vested with the power to resolve the issue (Article 288, LOSC). It is well to remember that a dispute hardly ever presents itself as a purely legal question, and often, raises both legal as well as political issues. This is true for most of the territorial and maritime disputes in Southeast Asia. These disputes not only test the limits of the dispute settlement provisions of the LOSC but also restrain the parties from considering international adjudicative processes as a viable alternative to resolve their longstanding unresolved territorial and maritime issues.

\subsubsection{The compulsory and binding nature of the LOSC dispute settlement regime}


The dispute settlement mechanism provided under the legal framework of LOSC establishes a compulsory and binding framework for the pacific settlement of all ocean-related disputes. (Rayfuse, 2005, pp. 683-711, Sheehan, 2005, pp. 165-190). The LOSC in Part XV requires States Parties to settle any dispute between them concerning the interpretation or application of the Convention by peaceful means in accordance with Article 2 (3), of the UN Charter "in such a manner that international peace and security, and justice, are not endangered." States parties are supposed to seek a solution by any of the means indicated in Article 33 (1), of the UN Charter, that is, through "negotiation, inquiry, mediation, conciliation, judicial settlement, resort to regional agencies or arrangements, other peaceful means of their choice."

The LOSC gives primacy for States to reach an agreement on the basis of international law in order to achieve an equitable solution in the delimitation of the EEZ and continental shelf between States (Article 74(1) and 83(1), LOSC). However, when States have been unable to reach agreement within "a reasonable time," the States concerned are obliged to resort to the procedures in Part XV of the Convention. (Articles 74(2) and 83(2), LOSC).

More importantly, submission to the compulsory procedures is not automatic since States may still reserve the right under Article 298 to have certain specified categories of disputes exempted from the compulsory fora. In such an instance, compulsory conciliation becomes the default procedure where Article 298(1)(a) operates to exempt a State or a dispute from compulsory adjudication. However, this only applies in a limited circumstance and the conciliation itself does not create a binding result. Thus far, it has never been initiated.

The optional exceptions to the compulsory procedure in Article 298 show the clear intention to remove maritime boundaries delimitation disputes from compulsory judicial settlement. These elaborate mechanisms are designed to preserve the sovereignty of States by giving the State parties the freedom to choose the manner by which they will settle their differences. (See and compare, Annex V, Article 3; Annex VI, Article 4; Annex VII, Article 3; and Annex VII, Article 3, LOSC; Treves, 1999; Adede, 1977)

The dispute settlement mechanism within the framework of the LOSC clearly creates an obligation among the claimant countries to settle their conflicting claims peacefully by any means of their own choice. (Article 280, LOSC; Adede, 1977-1978; Sohn, 1974-1975) 
However, McDorman asserts that the dispute settlement procedure of the LOSC is not part of customary law and, thus, is only binding upon those states which are parties to the LOSC. (2000, p. 259) Furthermore, the principle of peaceful settlement of international disputes operates on the basis of the sovereign equality of States, a fundamental premise upon which the whole architecture of international law operates. This implies that as a subject of international law, every State is equal to every other State, regardless of size, or even economic or political power. It is also independent and cannot be compelled to participate in any legal procedure without its consent. (Anand, 1966; Brown, 1915; Armstrong, 1920)

The compulsory settlement mechanism within the framework of the LOSC is triggered only as an option where the parties are not able to settle their differences by peaceful means of their choice. (Article 286, LOSC) But, even then, the submission of a dispute to such a forum depends on the willingness of the parties. In this regard, the dispute resolution mechanism may appear to offer no progress over previous regimes. This is actually not the case. In international law there is really no judicial forum with compulsory jurisdiction. Any form of third party dispute resolution is founded upon the assent of the parties involved. The lack of compulsion to submit to compulsory judicial forums under the LOSC is neither a serious drawback nor does it fall short of legitimate expectations. The LOSC dispute settlement regime improves upon the Optional Protocol system in the sense that in the case of the former, States become automatically bound by the compulsory procedures upon ratification of the LOSC; whereas under the latter, States become bound only when they become parties to the Protocol. Nonetheless, ultimately, this means still that the dispute settlement regime of the LOSC is only as good as the claimant States are willing to formally invoke it.

\subsubsection{The choice of procedure in LOSC disputes}

The LOSC provides the general rule that any dispute concerning the interpretation or application of the Convention, provided no settlement has been reached by the parties using any peaceful means of their choice, is subject to the system of compulsory procedures entailing binding decisions in Section 2, Part XV of the LOSC. (Article 286, LOSC) This is, of course, subject to the limitations and exceptions to the applicability of Section 2 of Part XV as specified in Section 3 of Part XV. (Articles 297 and 298, LOSC) The parties to a dispute 
have the obligation to exchange views (Article 283, LOSC) and to exhaust local remedies where this is required by international law. (Article 295, LOSC)

If a settlement has not been reached, the LOSC stipulates that the dispute be submitted at the request of any party to the dispute to a court or tribunal having jurisdiction in this regard. (Article 286, LOSC) The LOSC defines those courts or tribunals as: (a) the International Tribunal for the Law of the Sea (established in accordance with Annex VI of the Convention) including the Seabed Disputes Chamber; (b) the International Court of Justice; (c) an arbitral tribunal constituted in accordance with Annex VII of the Convention; and (d) a special arbitral tribunal constituted in accordance with Annex VIII for one or more of the categories of disputes specified therein. (Article 287, LOSC) The availability of a variety of forums was a compromise to secure consensus during the negotiations for the compulsory dispute settlement provisions of the LOSC. (Charney, 1996, 71)

The LOSC gives the State party the freedom to choose, by means of a written declaration submitted when signing, ratifying or acceding to the convention or at any time thereafter, one or more of the above courts or tribunals. (Article $287(1)$, LOSC) If States Parties to a dispute have accepted the same procedure, the dispute will be referred to that procedure, unless the parties agree otherwise. (Article 287(4), LOSC) If a State party to a dispute is not covered by a declaration in force, it shall be deemed to have accepted arbitration under Annex VII. (Article 287 (3), LOSC) If the States Parties to the dispute have not accepted the same procedure, the dispute may only be submitted to arbitration under Annex VII, unless the parties agree otherwise. (Article 287(5), LOSC)

\subsubsection{Limitations and exceptions to compulsory binding dispute settlement}

The prohibition upon States parties to make any reservations or exceptions to the Convention under Article 309 necessitated that exceptions and limitations had to be allowed in the compulsory dispute settlement regime of the LOSC, which is provided for in Section 3 of Part XV of the LOSC. These basically cover matters which are considered of vital national concern to a State to oblige it to submit to any binding dispute settlement regime. (Klein, 2009, p. 122) Specifically, there are two categories of disputes which are not covered by the compulsory procedures entailing binding decisions specified in Section 2: first, disputes with respect to discretionary decisions on permits for marine scientific research by 
a coastal State; (Article 297(2), LOSC) and secondly, disputes with respect to discretionary decisions on fisheries in a coastal State's EEZ. (Article 297(3), LOSC) The first category of dispute is subject to conciliation under Annex $V$ except questions relating to exercise of coastal State to designate specific areas or withhold consent in accordance with Article 246(6) and Article 246(5), respectively. The second category includes its discretionary powers for determining the allowable catch, its harvesting capacity, the allocation of surpluses to other States and the terms and conditions established in its conservation and management laws and regulations.

Section 3 of Part XV also allows States to declare in writing that it does not accept any of the procedures in Section 2 for certain categories of disputes. The State may do this when signing, ratifying or acceding to the LOSC or at any time thereafter. (Article 298 (1), LOSC) States may exclude the following disputes from the compulsory procedures entailing binding decisions in Section 2: disputes concerning the interpretation or application of Articles 15, 74 and 83 on maritime boundary delimitation, or those involving historic bays or titles; (Article 298 (1)(a)(i), LOSC) disputes concerning military activities; disputes concerning law enforcement activities in respect of rights and jurisdiction exercised by the coastal State over its EEZ resources; and disputes where the UN Security Council is exercising functions under the UN Charter. (Article 298(1)(c), LOSC)

\section{The Maritime Region of Southeast Asia}

Southeast Asia is predominantly a maritime region. About 80 per cent of it is covered by sea. It is therefore not a surprise that the sea dominates Southeast Asia. In pre-modern times, great Southeast Asian empires were established which were founded on the concept of sea power. In Southeast Asia, the sea is an important source of livelihood and food; and a source of maritime threats. The distinctively maritime character of the region makes the sea and issues with regard to the sea important in the international relations of the region. The maritime strategic geography of the Southeast Asian region has major implications for maritime security: first, the high density of shipping traffic in the region; second, the number of key straits and navigational chokepoints; and third, unresolved overlapping and contested maritime and territorial issues.

\subsection{Member States of Southeast Asia}


Geographically, Southeast Asia is a subregion of Asia, consisting of the countries that are geographically south of China, east of India, west of New Guinea and north of Australia. Most people think of the ten states comprising the Association of Southeast Asian Nations (ASEAN) as the complete listing of Southeast Asian states. These ten States are: Brunei, Burma (Myanmar), Cambodia, Indonesia, Laos, Malaysia, the Philippines, Singapore and Thailand, and Vietnam. However, from a strategic, military, security or even economic perspective, the Southeast region broadly defined is certainly bigger than ASEAN. In fact, the question of which States belong in ASEAN is a contentious issue in itself. Severino argues, thus: "One way of defining Southeast Asia, as the concept has evolved, is in terms of what it is not. It does not include China, Japan and Korea. Not Australia and New Zealand. Not India, or Bangladesh, which, until 1971, was part of Pakistan." (2006, p. 41) The sundry of regional or multilateral architecture of institutions in the region further blurs the distinction.

Of course, ASEAN is conspicuously the pre-eminent regional organization in Southeast Asia. The geo-political and economic organization ASEAN was formed in 1967 with its five original members: Indonesia, Malaysia, the Philippines, Singapore and Thailand. Since then, membership has expanded to further include five more states, Brunei, Burma (Myanmar), Laos, and Vietnam, and Cambodia, which was the last to join in 1999. Currently, accession negotiations are under way with two states, Papua New Guinea and East Timor. Then there is ASEAN plus 3, which includes the present members of ASEAN together with China, Japan, and South Korea. Then there is the East Asia Summit, which includes the present members of ASEAN Plus Three together with Australia, India, New Zealand, Russia and the United States. Finally, there is the ASEAN Regional Forum (ARF), an informal multilateral dialogue of 27 members that seeks to address security issues in the Asia-Pacific region whose membership includes the members of the East Asia Summit plus Bangladesh, Canada, Mongolia, North Korea, Pakistan, and the European Union (EU).

The list of States does get more and more problematic as the membership expands from the original ten members of ASEAN. It will certainly take great imagination and argument to include the EU or countries as distant as New Zealand or United States as part of Southeast Asia but this is definitely not the focus of this paper. 
Whilst the question of what States properly constitute the Southeast Asian region is beyond the scope of this paper, for its purposes, the analysis will be restricted to the member-States of ASEAN and China principally because of it being a claimant in the South China Sea.

\subsection{Territorial and maritime boundary disputes in Southeast Asia}

The semi-enclosed maritime spaces of Southeast Asia are said to be among the most disputed maritime spaces in the world. The region is host to a complex range of sovereignty disputes over territory as well as un-delimited maritime jurisdictional zones and entitlements arising out of disputed features involving multiple claimant States. The following list enumerates some of the territorial and maritime disputes in Southeast Asia:

- Territorial dispute between Laos and Thailand along the Mekong River

- Territorial dispute between Myanmar and Thailand along the Moei River

- Territorial dispute between Cambodia and Thailand in the Gulf of Thailand

- Territorial dispute between Cambodia and Vietnam in the Gulf of Thailand

- Territorial dispute between the Philippines and Malaysia over Sabah

- Territorial dispute between Malaysia and Brunei over Louisa Reef

- Territorial dispute between the Philippines and China over Scarborough Shoal

- Territorial dispute between the Philippines and China over Mischief Reef

- Territorial dispute between Brunei and Malaysia over Limbang Valley

- Maritime boundary in the Gulf of Tonkin between Vietnam and China

- Maritime boundary along the Vietnamese coast between Vietnam, China, and Taiwan

- Maritime boundary in the waters north of the Natuna Islands between Indonesia, China, and Taiwan

- Maritime boundary north of Borneo between Vietnam, China, Taiwan, Malaysia and Brunei

- Territorial and maritime boundary dispute over islands in the southern reaches of the South China Sea, including the Spratly Islands by Vietnam, Malaysia, The Philippines, Taiwan, and China

- Maritime boundary off the coast of central Philippines and Luzon between the Philippines, China, and Taiwan 
- Territorial and maritime boundary dispute over islands in the northern reaches of the South China Sea, including the Paracel Islands between Vietnam, China, and Taiwan

- Maritime boundary in the Luzon Strait between the Philippines and Taiwan

The above list of existing unresolved territorial and maritime boundary disputes in Southeast Asia is long and not exhaustive. In this regard, it seems natural for policy makers and even analysts to become pessimistic, agitated and cynical. Indeed, the task of resolving these disputes is herculean. However, there has also been much progress. The following is a list of settled territorial disputes and maritime boundary delimitation agreements in Southeast Asia:

- Case concerning Land Reclamation by Singapore in and around the Straits of Johor (Malaysia v Singapore): Settlement Agreement, 26 April 2005

- Agreement between the Government of the Socialist Republic of Vietnam and the Government of the Republic of Indonesia concerning the delimitation of the continental shelf boundary, 26 June 2003

- Agreement between the People's Republic of China and the Socialist Republic of Viet Nam on the delimitation of the territorial seas, the exclusive economic zones and continental shelves in Beibu Bay/Bac Bo Gulf, 25 December 2000

- Agreement between the Government of the Kingdom of Thailand and the Government of the Socialist Republic of Viet Nam on the delimitation of the maritime boundary between the two countries in the Gulf of Thailand, 9 August 1997

- Agreement between the Government of Malaysia and the Government of the Republic of Singapore to Delimit Precisely the Territorial Waters Boundary in Accordance with the Straits Settlements and Johore Territorial Waters Agreement 1927 (1995)

- Agreement between the Government of the Kingdom of Thailand and the Government of the Socialist Republic of the Union of Burma on the delimitation of the maritime boundary between the two countries in the Andaman Sea, 25 July 1980 
- Treaty between the Kingdom of Thailand and Malaysia relating to the delimitation of the territorial seas of the two countries, 24 October 1979

- Memorandum of Understanding between the Kingdom of Thailand and Malaysia on the delimitation of the continental shelf boundary between the two countries in the Gulf of Thailand (with map), 24 October 1979

- Agreement between the Government of the Kingdom of Thailand and the Government of the Republic of Indonesia relating to the delimitation of the sea-bed boundary between the two countries in the Andaman Sea, 11 December 1975

- Treaty between the Republic of Indonesia and the Republic of Singapore relating to the delimitation of the territorial seas of the two countries in the Strait of Singapore, 25 May 1973

- Agreement between the Government of the Republic of Indonesia, The Government of Malaysia and the Government of the Kingdom of Thailand Relating to the Delimitation of the Continental Shelf Boundaries in the Northern Part of the Strait of Malacca, 21 December 1971

- Agreement between the Government of the Kingdom of Thailand and the Government of the Republic of Indonesia relating to the delimitation of a continental shelf boundary between the two countries in the northern part of the Straits of Malacca and in the Andaman Sea, 17 December 1971

- Treaty between the Republic of Indonesia and Malaysia Relating to the delimitation of the Territorial Seas of the Two Countries in the Strait of Malacca, 17 March 1970

- Agreement between the Government of Malaysia and the Government of Indonesia on the delimitation of the continental shelves between the two countries, 27 October 1969

The above list is from the UN Division of Ocean Affairs and the Law of the Sea (DOALOS) website. It must be assumed that the list is not exhaustive. There are other extensive studies which discuss in detail the various territorial and maritime disputes in Southeast Asia, which are beyond the current scope of this paper.

\section{Opportunities, Challenges and Recommendations}




\subsection{Widespread ratification of the LOSC and willingness to negotiate on the basis of international law}

The Southeast Asian region, despite unresolved territorial and maritime issues, is largely peaceful and stable. The continuing reliance on international law by States to articulate their competing claims and positions as well as the widespread ratification of the LOSC contribute to regional peace and stability. China, as well as all the member States of ASEAN except for Cambodia, is a party to the LOSC. Cambodia signed the LOSC in 1983, but has yet to ratify it. This is both positive and promising. Many of the States in the region have enacted or revised domestic law in conformity with the Convention. The more recent ones include, the Law of the Sea of Viet Nam of 21 June 2012; and Republic Act No. 9522 which seeks to define the archipelagic baselines of the Philippines, enacted on 17 April 2009.

Many States in the region, including China, have also made submissions or preliminary information indicative of the outer limits of the continental shelf beyond 200 nautical miles to the UN Commission on the Limits of the Continental Shelf. The following have made preliminary submissions or information indicative of the outer limits of the continental shelf beyond 200 nautical miles to the UN Commission on the Limits of the Continental Shelf Brunei (12 May 2009); China (11 May 2009); Indonesia (16 June 2008); Malaysia-Vietnam joint submission (6 May 2009); Myanmar (16 December 2008); Philippines (8 April 2009); Vietnam (7 May 2009). Not all of these submissions are in dispute. In fact, it is only the joint submission by Malaysia and Vietnam which is relevant to the South China Sea and has elicited protests from other claimant States. On May 6, 2009, China through a note verbale challenged the joint submission made by Malaysia and Vietnam. In response, Vietnam and Malaysia lodged diplomatic counter-protests in response to China's protest in May 8 and 20, 2009, respectively. On August 4, 2009, the Philippines also filed a diplomatic protest over the submissions made by Vietnam and Malaysia. On April 5, 2011, the Philippines also filed a diplomatic protest in response to China's May 7, 2009 diplomatic protest.

Another significant stabilizing factor in the region is the 2002 Declaration on the Conduct of Parties in the South China Sea (DOC), signed by the member-States of ASEAN and China a decade ago. (Wu Shicun and Ren Huaifeng, 2003) This is the first time that China has signed a multilateral agreement, albeit one considered non-legally binding, on the issue of the 
South China Sea. In June 2003, Beijing signed the Treaty of Amity and Cooperation, which contains a dispute settlement procedure instituted among the ASEAN countries in June 1976, thereby agreeing not to "participate in any activity which shall constitute a threat to the political and economic stability, sovereignty, or territorial integrity" of the other signatory states. Taiwan, one of the six parties directly involved in the sovereignty and maritime jurisdictional dispute in the South China Sea, was excluded from regional efforts to formulate a code of conduct because of ASEAN's adherence to the "One-China Policy." Taiwan has also been barred from participating in other regional security dialogue processes, such as the ASEAN Regional Forum (ARF). (Song, 2000)

The Declaration is a testimony to regional efforts that spanned almost a decade of intense negotiations, underscoring the importance of regional security and the establishment of mutual trust and confidence among all the claimant countries. The Declaration reaffirmed the commitment of all the claimant countries to universally-recognized principles of international law including the UN Charter and the LOSC. (See, Preamble, Declaration, 2002) The Declaration likewise affirmed the 1976 Treaty of Amity and Cooperation in Southeast Asia between ASEAN members, and the Five Principles of Peaceful Coexistence (1954).

The Declaration is a political document, and consequently, not legally binding. (Buszynski, 2003; Thao, 2000) It likewise does not resolve the competing claims of territorial sovereignty issues in the South China Sea nor does it impose any enforceable obligations on the parties. However, the greater significance of the Declaration lies in the commitment of the parties to the maintenance of peace and stability, which are requisites to regional growth and development. The Declaration evinces the intent of all the parties to sustain negotiations conducted in good faith towards the eventual resolution of the issue. Most importantly, the Declaration has substantially improved the level of trust and confidence among the claimant countries and has been instrumental in other bilateral and multilateral initiatives that build upon its principles.

However, despite the lapse of over a decade since the DOC was signed, the parties have yet to agree on a Code of Conduct (COC) for the South China Sea. Still, there have been some assuring developments such as the adoption of the Guidelines to Implement the DOC in July 2011 and the adoption of the Six-Point Principles on the South China Sea in July 2012. 
In general, States in the region profess their willingness to negotiate on the basis of international law and in particular the provisions of the LOSC. Since almost all of the States with territorial and maritime delimitation disputes in the region are signatories or parties to the LOSC, they have the primary obligation under Part XV to resolve their disputes by peaceful means. (Article 279, LOSC) However, even without going through the formal compulsory procedure in any of the fora available, the claimant countries using the other substantive provisions of the LOSC may define their maritime zone claims in accordance with the rules established in the LOSC. These may include the following: (1) specification of their precise claims; (2) drawing and publishing the proper basepoints and baselines along their coasts; and (3) negotiating to agree which features are islands. For example, almost all of the coastal States in East and Southeast Asia have implemented straight baselines which

have been criticized as being "excessive," (Roach and Smith, 2000, pp. 47-80) and clearly breach many of the conditions laid down in Article 7 of the LOSC. (Bateman and Schofield, 2008, pp. 8-16) Since the starting point for the delimitation of maritime boundaries is often the construction of strict equidistance or median lines, excessive straight baseline claims need to be adjusted since such potentially deflect the line of equidistance to the distinct advantage of the State that constructed them, which can then complicate maritime boundary delimitation negotiations.

\subsection{Reluctance to submit disputes to international adjudication}

The likelihood of a dispute in the region to be submitted to an international tribunal for resolution appears to be remote. There seems to be a general reluctance among Asian countries to submit their disputes for international adjudication. (Palmer, 1998, p. 579). However, the general reluctance to adjudicate is not unique to Southeast Asian countries. Notably and in sharp contrast, in other disputes, involving trade, for instance, the same States hesitant to resolve their territorial and maritime disputes utilizing formal international adjudicative procedures and forums will readily submit cases to the dispute settlement procedures of the World Trade Organization.

It will be too simplistic and not entirely accurate to ascribe this disinclination to purely cultural reasons. It will be hard to over-generalize and assert a universal Asian culture in this regard. However, the significant role of cultural subtleties in the international relations of 
Southeast Asian States, and in fact, even elsewhere, is undeniable. In formal and covert dispute resolutions mechanisms, there are winners and losers, which undoubtedly make one of the parties lose face, a situation which the States find unacceptable and try hard to avoid if possible. The high degree of emotions involved in maritime and territorial disputes in Asia, and the importance that Asian culture places on the maintenance of goodneighborly relations and peace, make them reluctant to bring their neighboring States to a third-party dispute settlement procedure.

In addition to the abovementioned cultural reasons, the time and exorbitant costs involved in undertaking a case in any of the available international fora also discourage countries in Southeast Asia. Another possible reason why submitting the dispute to international adjudication is not under serious consideration is that the basis of their respective claims are not especially compelling in international law terms. (Schofield and Storey, 2009, p. 10). There are other pragmatic factors such as intra and extra-regional power imbalances as well as deepening economic interdependence amongst the States of the region which are disincentives due to the possible economic and trade repercussions of a disruption in friendly relations between States involved in a dispute.

The States in the region have very little experience in litigation at the international level with regard to the settlement of territorial and maritime disputes. As previously mentioned in an earlier section, only three disputes have referred to the ICJ, two cases submitted to ITLOS, and three to the PCA. The majority of territorial disputes in Southeast Asia have very little likelihood of being resolved this way, as submission to an international tribunal is seen by States across the region as a remedy of last resort preferring bilateral dispute resolution instead. (Charney and Alexander, 1993, pp. 915, 1057, 1135, 1145) Moreover, many States in the region do not recognize the compulsory jurisdiction of the ICJ, such as China, Vietnam, Malaysia and Brunei. While the Philippines does, it has made a reservation that excludes territorial disputes from its acceptance of the ICJ's compulsory jurisdiction submitted on 18 January 1972. Since the consent of the parties is the basis of ICJ jurisdiction, if the above States choose to bring their territorial and maritime disputes to the ICJ, they must first sign a special agreement accepting the jurisdiction of the ICJ. Despite its pre-eminence as an international forum, two-thirds of States, including China, have not submitted a case to the ICJ. (Posner and Figueiredo, 2005, 614). The other reasons why States hesitate to submit a 
dispute to the ICJ for resolution include concerns over its partiality, which consequently affects compliance. (Posner and Figueiredo, 2005, pp. 608-610; Mackenzie and Sands, 2003, p. 275) Posner and Figueiredo, using statistical methods, interrogated the charge of bias against judges of the ICJ and found strong evidence that judges favor the states that appoint them and whose wealth level is close to their own states. (Posner and Figueiredo, 2005, p. 624)

The submission of a territorial and maritime boundary dispute to ITLOS does not appear to be an accepted mode of settling territorial and maritime disputes in the region or elsewhere. In fact, to date, there has only been one such case filed with ITLOS: the case concerning delimitation of the maritime boundary between Bangladesh and Myanmar in the Bay of Bengal between Bangladesh and Myanmar, decided by ITLOS in 2012. Annex VII arbitrations appear to be more utilized, with at least three cases filed with the PCA by States in the region as mentioned above.

The 2013 Annex VII arbitration case by the Philippines against China over the West Philippine Sea -- currently pending with the PCA -- appears to be a positive development in the use of LOSC dispute settlement procedures. On the other hand, China refused to participate in the arbitral proceedings insisting that the dispute be resolved bilaterally through other diplomatic means. It is definitely possible and foreseeable for any of the other claimant states to submit a similar petition for international adjudication. However, given the current geopolitical, economic and military conditions in the region, this appears remote at the moment. At this stage, the other claimant States as well as the rest of the world are awaiting how the arbitral tribunal will decide both the prejudicial question of jurisdiction as well as the merits of the Philippine submission.

Whilst the LOSC allows States parties to the Convention to choose at any time its preferred choice of procedure for the settlement of disputes (Article 287 (1), LOSC), none of the claimant States over the South China Sea has done so. In effect, this means that if a dispute arises between any of the claimant States, it may only be submitted to arbitration in accordance with Annex VII, unless the parties decide otherwise. (Article 287(5), LOSC)

The Convention further allows States parties at any time to declare in writing that they do not accept any of the compulsory procedures under Section 2 for certain categories of 
disputes (Article 298, LOSC). China, on 25 August 2006, has exercised this right and has submitted a Declaration under Article 298 of the Convention, as follows:

The Government of the People's Republic of China does not accept any of the procedures provided for in Section 2 of Part XV of the Convention with respect to all the categories of disputes referred to in paragraph 1 (a) (b) and (c) of Article 298 of the Convention. (China Declaration, 2006)

\subsection{Recommendations}

International law allows a number of mechanisms for the avoidance and settlement of disputes, which includes political means such as negotiation and consultation, mediation and good offices, conciliation, investigation, and such judicial means as arbitration and international adjudication. This section will examine some of these modes of adjudication or dispute resolution in the Southeast Asian context.

\subsubsection{Submit disputes to international adjudication}

International adjudication is a method of international dispute settlement that involves the referral of the dispute to an impartial third-party tribunal--normally either an arbitral tribunal or an international court--for binding decision, usually on the basis of international law. While the discussion above alluded to the reluctance of most States in the region to submit their disputes to an international tribunal, a long-term goal among States to ensure lasting resolution to their disputes should include the submission of their dispute to a third party for settlement. Of course, this does not preclude States from resolving their disputes bilaterally through diplomatic means in order to arrive at an agreement. The claimant States should show their sincerity in their desire to settle their disputes and their political maturity as independent modern nations in the international community by seeking a mutually acceptable settlement by negotiations, and failing such, by submitting their disputes to a third party for settlement.

\subsubsection{Explore other methods of dispute resolution}

There are other methods of dispute resolution available at the international level, including negotiation, mediation, and diplomacy. These alternative modes of dispute resolution 
should be viewed within the context of the various regional initiatives and fora. For example, the potential for militarized conflict over a number of territorial as well inter-State disputes in the ASEAN has been mitigated, if not always avoided, by the development of the key ASEAN norms of non-intervention in the internal affairs of another State and the respect for the independence and sovereignty of each member State. These norms are embodied in ASEAN's 1976 Treaty of Amity and Cooperation (TAC) in Southeast Asia. The TAC, some scholars have argued, is the central pillar of ASEAN and the source of the norms of nonconfrontation and consensus building which is the key in maintaining peace, stability and order in the region. The enduring presence of maritime tension over disputed territories between and among the various ASEAN States may be unavoidable altogether but the commitment of the member States to building regional cooperation and the institutionalization of multilateral fora have prevented the escalation or eruption of military confrontation and war. The 2002 Declaration on the Conduct of Parties in the South China Sea signed by ASEAN countries and China evinced a willingness among claimants to resolve disputes by peaceful means, to exercise self-restraint, and to approach the dispute multilaterally. While it has not entirely eliminated unilateral actions by claimants in the South China Sea, it has definitely dissipated some tension among the claimants and provided a venue to address the issue within the region diplomatically.

There are some current developments within the framework of ASEAN which could potentially expand the role of ASEAN in settling intra-regional disputes. These include the adoption of the ASEAN Charter which includes a chapter which deals with issues pertaining to the settlement of disputes, and the adoption of the ASEAN Dispute Settlement Mechanisms (DSM) on April 2009 to address disputes arising from the differences in the interpretation and application of the Charter as well as other ASEAN instruments. The DSM provides for a variety of means to settle disagreements, including consultation between parties, mediation, and arbitration, and the referral of unresolved disputes to the ASEAN summit.

\subsubsection{Explore option of focusing on less substantive issues not involving sovereignty} issues, including considering joint development of resources as an option 
The positions of the individual countries who have maritime or territorial disputes with one another may seem intractable from a domestic politics point of view, creating an impediment for negotiations to proceed. However, on other issues of a more benign nature such as trade or issues that transcend boundaries such as marine environmental protection and marine scientific research, or issues of grave importance such as terrorism, the countries have invariably been more than willing to set aside their positions and cooperate with other States, even with those States they have maritime or territorial disputes with. In these instances, their differences in position are more prudently construed and interpreted, and take on secondary importance to other issues, thus, permitting cooperation. The parties can also deliberately set aside the issue of sovereignty and consider joint development of the resources as an option without prejudice to their respective claims.

However, while developing countries are keen to promote investments in maritime areas that are subject to competing sovereignty disputes or overlapping claims, investors are expectedly wary. The failure to settle overlapping claims have made such areas as the South China Sea and the Aegean Sea unattractive to investors. However, as has been shown in the case of Red Sea region with respect to minerals between Sudan and Saudi Arabia; and the Timor Sea in the case of petroleum between Indonesia and Australia, coastal States may be willing to resort to the joint development of mineral deposits in areas of overlapping claims even in the absence of an agreement to settle their claims. The Joint Marine Scientific Undertaking (JMSU) signed by the State-owned oil companies of China, Vietnam and the Philippines in March 2005 in order to identify oil and natural gas deposits for possible future development is indicative of the political will of the States to develop the disputed area jointly and their common desire to benefit from the natural resources in the disputed area. The JMSU was signed on 14 March 2005 by the Philippine National Oil Company (PNOC), China National Offshore Oil Corporation (CNOOC) and Vietnam Oil and Gas Corporation (PetroVietnam). However, the JMSU lapsed in June 2008 and was not extended by the parties; and since the JMSU ended, no other cooperative undertakings among the disputants have been launched.

\subsubsection{Capacity-building among States in Southeast Asia}


States within the Southeast Asian region are at varying stages of economic development with varying priorities and national goals. The countries in the region are also marked by great disparities among them in terms of naval and military strengths. There is also room for strategic analysis in this respect. The growing economic power of China, in the region and beyond, has drastically altered the regional economic and military balance, which has enabled China to expand its political and diplomatic sphere of influence. The potential impact of China's reach has caused concern all across the East Asian mainland, the Indian Ocean region and made the United States uneasy. The March 2009 incident involving the USNS Impeccable brought to fore issues concerning China's growing assertiveness in enforcing what it regards as its maritime rights and China's interpretation of international maritime law, which in some instances are not shared by other States. The modernization of the PLA Navy and its plan to develop blue-water capabilities which will give it the capacity to project its power into the region and beyond will affect the maritime strategic environment as well as the tone and tenor of dialogue on regional maritime disputes.

However, instead of a military build-up in the interim before their disputes are submitted for international adjudication, the States in the region should focus on securing for themselves the necessary resources to develop the capacity in other areas equally important in the resolution of their maritime and territorial disputes -- such as the ratification of and compliance with the relevant international instruments, the drawing of legally defensible baselines, and improved capacity for maritime regulation and enforcement, among others.

Governments across the region are aware that clearly-defined maritime boundaries are indispensable for good relations among States and effective ocean management. However, only a few coastal States have agreed maritime boundaries with their neighbors. In the case of many of the States in the region, the lack of a range of specialist legal and technical skills required in boundary delimitation could be a serious impediment.

\section{Conclusion}

The persistent territorial disputes over maritime territories in Southeast Asia challenge the peace and stability of the region. There is also the issue of unexplored resources which cannot be utilized and exploited because of sovereignty disputes. Often, disputed islands 
and rocks have little value per se. However, their real value lies in the maritime zones that they could potentially generate which may contain valuable fisheries stocks and potential mineral deposits such oil and gas. While it can be safely asserted that the region is largely at peace and the disputes have not erupted into sustained military conflict, there still exist intermittent tensions among the rival claimants. In the course of articulating or advancing their respective claims to disputed maritime areas, countries will often assert legal and historical arguments in support of their claims and will take various steps to occupy disputed territory. This is the same scenario in the disputed territories in Southeast Asia. As a result of these postures, tensions remain high and the potential for armed conflict remains. Thus, the States involved must remain committed to cooperation, diplomacy and the use of peaceful means of settling the disputes.

The value of establishing maritime boundaries that are of sound basis in international law and therefore respected by the international community is self-evident. The fundamental purpose of maritime boundary delimitation is to provide clarity and certainty to all maritime States and users in order to minimize inter-state conflict and promote the sustainable management and governance of the oceans. Uncertain boundaries increase political and security risks. Unresolved boundaries have serious economic consequences as such may stall exploration of resources, disrupt fishing or impede shipping; hamper environmental conservation measures; and may also trigger intense diplomatic disputes affecting economic relations. Conversely, the certainty of a nation's boundaries enhances stability and promotes peaceful relations among neighboring States sharing the same boundaries and resources.

The LOSC constitutes the primary legal framework in addressing the conflicting maritime claims in Southeast Asia, particularly in the South China Sea. The LOSC is binding upon all claimant countries to the South China Sea, with the exception of Taiwan, all being parties to it. This fact need not be overstressed since all the parties to the dispute invariably invoke the provisions of the LOSC as a basis for their respective claims.

The LOSC clearly creates an obligation among claimant countries to settle their conflicting claims peacefully, using any of forums specified under the UN Charter and the Convention itself. However, since the dispute settlement mechanism within the framework of the LOSC 
operates on the basis of the sovereign equality of states, the submission of a dispute to such a forum depends on the willingness of the parties. Moreover, while the legal framework under the LOSC offers some options, the highly complicated nature of the disputes in the Southeast Asian region especially those pertaining to the overlapping and conflicting claims over the South China Sea, tests the limits of international law and obscures the possibility of a legal solution. Moreover, the cultural aversion of Asians against a judicial settlement, where there are victors and losers, almost renders this option illusory. (Bautista, 2007, p. 701)

The option for joint development and other practical cooperative mechanisms should continue to remain, and is always a positive development while issues of sovereignty remain unresolved. Increasing functional cooperation in other areas, aside from trade, such as in areas of security, educational, cultural, and scientific cooperation, marine environmental protection and marine scientific research, among others, should be encouraged. The LOSC prescribes provisional arrangements of a practical nature (Article $74(3)$ and $83(3)$, LOSC) during the transitional phase before a final agreement is reached in overlapping EEZ or continental shelves. In respect of the South China Sea disputes, determining the area which may be subject to joint development is essentially problematic since sovereignty is disputed and the status of the features and maritime zones they could potentially generate are likewise ambiguous.

Notwithstanding heightened tensions in the region, the possibility of actual armed or militarized conflict over territorial disputes appears to be remote. The submission of existing disputes to legally-binding dispute settlement mechanisms appears unlikely. That said, the Philippine Annex VII arbitration case against China over the South China Sea should be seen as a positive move in the right direction. It is good to remember that an essential factual precursor prior to the filing of the case was the 2012 standoff between China and the Philippines over Scarborough Shoal. (Bautista, 2013) In the midst of intense diplomatic, trade and even threat of actual use of armed force, the Philippines has chosen instead to file the arbitration case to resolve the dispute with China. While the factual situation on the ground highlighted the stark asymmetry between the economic power and military capabilities of the two countries, the resort to arbitration highlighted the perception of international law as a more level playing where the rule of law still reigns supreme. 
The non-participation of China in the arbitration, although regrettable, is part of its sovereign prerogative. The ruling of the arbitration panel as well as history itself and global public opinion will be the ultimate judges if indeed China has chosen the appropriate tactical move in this conflict. Nonetheless, overall, there is a continuing reliance and use of international law terminology and notably LOSC provisions in the articulation of the respective claims by States in the region. This has led not just to greater clarity amongst the claimant States of their positions but has also prevented conflict. Thus, the LOSC, including its dispute settlement regime, will continue to play a substantial role in the eventual resolution of the competing territorial and maritime jurisdictional claims in Southeast Asia.

\section{Notes:}

This is a revised and updated version of a paper of the same title presented by the author at "UNCLOS at 30", International Conference for the Anniversary of Signature of the United Nations Convention on the Law of the Sea, Qingdao, China, 22-24 November 2012. The author is grateful for the insightful comments of the two anonymous reviewers of this paper. 


\section{References}

Adede, A. O. (1977). "Law of the Sea: The Scope of the Third Party, Compulsory Procedures for Settlement of Disputes." American Journal of International Law, 71, 305 - 311.

Adede, A.O. (1987). The System for Settlement of Disputes under the United Nations Convention on the Law of the Sea. Dordrecht: Martinus Nijhoff.

Amerasinghe, Chittharanjan Felix (2009). Jurisdiction of Specific International Tribunals. Leiden: Martinus Nijjhoff.

Anand, R.P. (1966). "Sovereign Equality of States in International Law." International Studies, 8, 213-241.

Antunes, Nuno Sergio Marques (2003). Towards the Conceptualisation of Maritime Delimitation: Legal and Technical Aspects of a Political Process. Leiden; Boston: Martinus Nijhoff.

Armstrong, S. W. (1920). "The Doctrine of the Equality of Nations in International Law and the Relation of the Doctrine to the Treaty of Versailles." The American Journal of International Law, 14, 540-564.

Bateman, Sam and Schofield, Clive (2008). "State Practice Regarding Straight Baselines in East Asia - Legal, Technical and Political Issues in a Changing Environment" (paper presented at the International Conference on Difficulties in Implementing the Provisions of UNCLOS, organised by the Advisory Board on the Law of the Sea (ABLOS), Monaco, 16-17 October 2008.

Bautista, Lowell B. (2007). "Thinking Outside the Box: The South China Sea Issue and the United Nations Convention on the Law of the Sea (Options, Limitations and Prospects)." Philippine Law Journal, 81, 699 - 731.

Bautista, Lowell B. (2013). "The Philippine Claim to Bajo de Masinloc in the Context of the South China Sea Dispute." Journal of East Asia and International Law, 6, 497-529. 
Blake, Gerald (1998). Hydrocarbon and International Boundaries: A Global Overview. In Gerald Blake, et al. (Eds.) Boundaries and Energy: Problems and Prospects (London; (3-27). Boston: Kluwer Law International.

Brown, Philip Marshall (1915). "The Theory of the Independence and Equality of States." The American Journal of International Law, 9, 305-335.

Brownlie, Ian (2002). International Law and the Use of Force by States. Oxford: Oxford University Press.

Brownlie, Ian (2008). Principles of Public International Law. Oxford: Oxford University Press.

Buszynski, Leszek (2003). "ASEAN, the Declaration on Conduct, and the South China Sea" Contemporary Southeast Asia, 25, 343-362.

Buszynski, Leszek and Sazlan, Iskandar (2007). "Maritime Claims and Energy Cooperation in the South China Sea," Contemporary Southeast Asia 29, 143-171.

Case Concerning Military and Paramilitary Activities in and against Nicaragua (Nicaragua v. United States of America), Jurisdiction and Admissibility, Judgment of 26 November 1984, 1984 ICJ Rep. 293

Charney, Jonathan (1996). "The Implications of Expanding International Dispute Settlement Systems: The 1982 Convention on the Law the Sea." American Journal of International Law, 90, 69-75.

Charney, Jonathan I. (1994). "Progress in International Maritime Boundary Delimitation Law," American Journal of International Law 88, 227-256.

Charney, Jonathan I. and Alexander, Lewis M. (1993). International Maritime Boundaries. Dordrecht; Boston: Martinus Nijhoff.

Charter of the United Nations, concluded on 26 June 1945, entered into force on 24 September 1945, 59 Stat. 1031, TS 993, 3 Bevans 1153.

China, Declaration under Article 298 made after ratification, 25 August 2006. 
Corfu Channel Case (United Kingdom of Great Britain and Northern Ireland v. Albania) (Merits) 1949 ICJ 4; 16 AD 155

Declaration on the Conduct of Parties in the South China Sea, 4 November 2002, Phnom Penh, Kingdom of Cambodia.

Dillon, Dana R. (2011). "Countering Beijing in the South China Sea." Policy Review, 167, 5167.

Gray, Christine D. (2008). International Law and the Use of Force. Oxford; New York: Oxford University Press.

Jennings, Robert (1963). The Acquisition of Territory in International Law. Manchester: Manchester University Press.

Kaikobad, Kaiyan Homi (2002). "Problems of Adjudication and Arbitration in Maritime Boundary Disputes," Law and Practice of International Courts and Tribunals 1, 1-86.

Klein, Natalie (2009). Dispute Settlement in the UN Convention on the Law of the Sea. Cambridge, England: Cambridge University Press.

Kwiatkowska, Barbara (1993). Economic and Environmental Considerations in Maritime Boundary Delimitation. In Jonathan I. Charney and Lewis M. Alexander (Eds.) International Maritime Boundaries (75-113). Dordrecht; Boston: Martinus Nijhoff.

Kwiatkowska, Barbara (2002). Decisions of the World Court Relevant to the UN Convention on the Law of the Sea: a Reference Guide. The Hague: Kluwer Law International Kluwer Law International.

Lauterpacht, Hersch (2011). The Function of Law in the International Community. Oxford: Oxford University Press.

Law of the Sea of Viet Nam, 21 June 2012;

Legal Consequences of the Construction of a Wall in the Occupied Palestinian Territory, Advisory Opinion of 9 July 2004, 2004 ICJ Rep. 136 
Mavrommatis Palestine Concessions (Greece v. Great Britain), Judgment of 30 August 1924, 1924 PCIJ (Ser. A) No. 2

McDorman, Ted L. (2000). “Global Ocean Governance and International Adjudicative Dispute Resolution." 43 Ocean and Coastal Management, 43, 255 -275.

Mackenzie, Ruth and Sands, Philippe (2003). "International Courts and Tribunals and the Independence of the International Judge." Harvard International Law Journal, 44, 271-285.

Palmer, Geoffrey. (1998). International Law and the Reform of the International Court of Justice. In Antony Anghie and Garry Sturgess (Eds.), Legal Visions of the 21st Century: Essays in Honour of Judge Christopher Weeramantry (579-600). The Hague, Netherlands: Kluwer Law International.

Posner, Eric A. and Figueiredo, Miguel FP de (2005). "Is the International Court of Justice Biased?." Journal of Legal Studies, 34, 599-630.

Prabhakar, W. Lawrence S. (2007). "The Regional Dimension of Territorial and Maritime Disputes in Southeast Asia," In Kwa Chong Guan and John K. Skogan (Eds.), Maritime Security in Southeast Asia (34-48). London: Routledge.

Prescott, Victor and Schofield, Clive. The Maritime Political Boundaries of the World. Leiden; Boston: Martinus Nijhoff.

Rayfuse, Rosemary Gail, (2005). "The Future of Compulsory Dispute Settlement under the Law of the Sea Convention." Victoria University of Wellington Law Review 30, 683711

Republic Act No. 9522: An Act to Amend Certain Provisions of Republic Act No. 3046, as Amended by Republic Act No. 5446, to Define the Archipelagic Baselines of the Philippines, 17 April 2009.

Roach, J. Ashley and Smith, Robert W. (2000). "Straight Baselines: The Need for a Universally Applied Norm." Ocean Development and International Law, 31, 47-80. 
Schofield, Clive and Storey, Ian (2009). The South China Sea Dispute: Increasing Stakes and Rising Tensions. Washington, D.C.: The Jamestown Foundation.

Schreuer, Christoph (2008). What is a Legal Dispute? In Buffard, I., et al (Eds.), International Law between Universalism and Fragmentation Festschrift in Honour of Gerhard Hafner (959-980). Leiden, the Netherlands: Brill.

Sharma, Surya, (1997). Territorial Acquisition, Disputes, and International Law. The Hague; Boston: Martinus Nijhoff.

Shaw, Malcolm (2008). International Law. Cambridge: Cambridge University Press.

Sheehan, Ann (2005). "Dispute Settlement under UNCLOS: The Exclusion of Maritime Delimitation." University of Queensland Law Journal, 24, 165-190.

Smith, Robert W. (1982). "A Geographical Primer to Maritime Boundary-Making," Ocean Development and International Law, 12, 1-22.

Song, Yann-Huei (2000). "Codes of Conduct in the South China Sea and Taiwan's Stand." Marine Policy, 24, 449.

Starke, J. G., (1984). Introduction to International Law. London: Butterworths.

Statute of the International Court of Justice, concluded on 26 June 1945, entered into force on 24 September 1945, 3 Bevans 1179; 59 Stat. 1031; T.S. 993; 39 AJIL Supp. 215 (1945).

Territorial and Maritime Dispute (Nicaragua v. Colombia) Judgment of 19 November 2012.

Thao, Nguyen Hong (2000). "Vietnam and the Code of Conduct for the South China Sea." Ocean Development and International Law, 32, 105-130.

To, Lee Lai (1999). "The South China Sea: China and Multilateral Dialogues." Security Dialogue, 30, $165-178$.

Treaty of Amity and Cooperation in Southeast Asia, Indonesia, 24 February 1976. 
Treves, Tullio (1999). "Conflicts between the International Tribunal for the Law of the Sea and the International Court of Justice." New York University Journal of International Law and Policy, 31, 809-821.

United Nations Convention on the Law of the Sea, opened for signature 10 December 1982, 1833 UNTS 3 (entered into force 16 November 1994).

Wu, Shicun and Ren, Huaifeng (2003). "More than a Declaration: A Commentary on the Background and the Significance of the Declaration on the Conduct of the Parties in the South China Sea." Chinese Journal of International Law, 2, 311 - 319. 